\title{
DÜBLIN
}

Technological University Dublin

ARROW@TU Dublin

\section{Study of the Microbial Diversity and Antimicrobial Properties of Irish Edible Brown Seaweeds}

\author{
Shilpi Gupta \\ Technological University Dublin, shilpi.19may@gmail.com \\ Gaurav Rajauria \\ Technological University Dublin, gaurav.rajauria@tudublin.ie \\ Nissreen Abu-Ghannam \\ Technological University Dublin, nissreen.abughannam@tudublin.ie
}

Follow this and additional works at: https://arrow.tudublin.ie/schfsehart

Part of the Food Chemistry Commons, Food Microbiology Commons, and the Food Processing Commons

\section{Recommended Citation}

Gupta, S. Rajauria, G. \& Abu-Ghannam, N. (2010) Study of the Microbial Diversity and Antimicrobial Properties of Irish Edible Brown Seaweeds. International Journal of Food Science and Technology 45: 482-489 doi:10.1111/j.1365-2621.2009.02149.x

This Article is brought to you for free and open access by the School of Food Science and Environmental Health at ARROW@TU Dublin. It has been accepted for inclusion in Articles by an authorized administrator of ARROW@TU

Dublin. For more information, please contact

arrow.admin@tudublin.ie, aisling.coyne@tudublin.ie, gerard.connolly@tudublin.ie.

Funder: Irish government (Strand III)

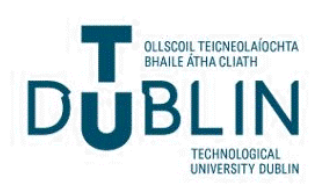




\title{
Original article \\ Study of the microbial diversity and antimicrobial properties of Irish edible brown seaweeds
}

\author{
Shilpi Gupta, Gaurav Rajauria \& Nissreen Abu-Ghannam* \\ School of Food Science and Environmental Health, Dublin Institute of Technology,Cathal Brugha St., Dublin 1, Ireland
}

(Received 2 August 2009; Accepted in revised form 24 November 2009)

Summary Brown Irish edible seaweeds, Himanthalia elongata, Laminaria sachharina and Laminaria digitata, were evaluated for the microbiota in raw and heat processed form. Raw seaweeds showed complete absence of aerobic mesophiles, halophiles, yeasts and molds. However, heating at $85{ }^{\circ} \mathrm{C}$ for $15 \mathrm{~min}$ resulted in spore germination. Bacterial counts as high as $10^{7}$ were observed for aerobic mesophiles and halophiles. Heating above $95{ }^{\circ} \mathrm{C}$ for $15 \mathrm{~min}$ resulted in complete inactivation of surface microflora. Bacteria belonging to Bacillaceae, Paenibacillaceae, Moraxellaceae and Enterobacteriaceae family were identified by 16S rRNA sequencing. In vitro antimicrobial activity of the methanolic extracts of the seaweed on food pathogenic and food spoilage bacteria were also evaluated. The seaweeds in their raw state had almost $100 \%$ inhibition against Listeria monocytogenes; $98 \%$ and $93 \%$ inhibition was achieved against Pseudomonas aeruginosa by H. elongata and L. saccharina extracts, respectively. Heating the seaweeds resulted in the reduction of antimicrobial activity as compared to raw. The effect was more pronounced against Gram negative bacteria.

Keywords Aerobic plate count, antimicrobial activity, halophiles, Irish brown seaweeds, microbiological diversity.

\section{Introduction}

Seaweeds are considered a valuable source of bioactive compounds as they are able to produce a great variety of secondary metabolites characterised by a broad spectrum of biological activities. They are also rich in polysaccharides such as alginates, fucans, and laminarans which have been reported to possess potential medicinal values and are also considered as dietary fibres (Smit, 2004). The human consumption of algal fibre promotes the growth and protection of the beneficial intestinal flora. Seaweeds are divided into three categories depending upon their nutritional and chemical composition as brown, red and green algae. Brown seaweeds are known to contain more bioactive components than either green or red seaweeds (Seafood plus, 2008). Marine algae in human consumption have been documented since 600 BC. In China, Japan, France, and Chile, seaweeds are harvested to be included in a great variety of dishes, including sushi wrappings, salads, soups, and condiments. The major seaweeds that are of dietary importance in Asian countries belong to the genus Undaria, Porphyra and Laminaria. Recently, other countries, such as the USA, South America, Ireland, Iceland, and France have significantly

*Correspondent: E-mail: nissreen.abughannam@dit.ie increased the consumption, production and marketing of seaweeds (McHugh, 2003). The Atlantic coast of Ireland is one of the most productive seaweed growing areas in the world. Its climate, over $5000 \mathrm{~km}$ of rocky habitat, abundance of nutrient-rich waters and large tidal flow makes it an ideal habitat for seaweed growth. More than 600 different species of seaweed have been identified in Irish waters. However, there are no specific regulations governing the collection of this product from coastal regions and it may be collected from inshore marine waters as well as from agricultural run-off which may perhaps be a source of contamination. The retail of fresh seaweeds is limited and the harvest is processed in order to ensure preservation by drying, freezing or fermenting. Not much literature is available investigating the microbiology of this material. Hence, the present study was performed to characterise the brown Irish seaweeds with respect to their biodiversity and the effects of heat on its microbiota.

Artificial food preservatives are generally used to inhibit the growth of food spoilage micro-organisms. Plant extracts are an important source for the extraction and isolation of natural antimicrobials which could inhibit the growth of spoilage organisms. Although seaweeds are rich in bioactives and can be used as nutraceuticals and functional foods, little information is available regarding the stability of their antimicrobial 
activity during heating. Commercially in processing plants or domestically in household kitchens, fruits and vegetables undergo heat treatment. The degree to which phytochemicals change during processing depends on their sensitivity to modifications or degradations, and length of exposure to a processing technique (Breena, 1994).

Use of brown seaweeds as a food source is slowly gaining popularity. Thus, this present work was designed to study the microbiological diversity of the brown edible Irish seaweeds. In addition, their antimicrobial properties and the effect of heat on the bioactivity were also investigated.

\section{Materials and methods}

\section{Seaweed material}

Three species of brown edible Irish seaweeds namely, Laminaria digitata, Laminaria saccharina and Himanthalia elongata (Phaeophyta) were purchased from Quality Sea Veg., Co Donegal, Ireland. Samples were collected in September 2008, washed thoroughly with freshwater to remove epiphytes and eliminate foreign materials such as sand or shells and stored at $-18{ }^{\circ} \mathrm{C}$ until analysis.

\section{Seaweeds treatment}

For all the experiments, raw and heat treated seaweeds were used. Heat treatment were carried out in an autoclave (Tomy SS-325, Tomy Seiko Co. Ltd, Tokyo, Japan) at the following conditions: $85^{\circ} \mathrm{C}$ for $15 \mathrm{~min}$, $85^{\circ} \mathrm{C}$ for $30 \mathrm{~min}, 95^{\circ} \mathrm{C}$ for $15 \mathrm{~min}, 100{ }^{\circ} \mathrm{C}$ for $15 \mathrm{~min}$, $110{ }^{\circ} \mathrm{C}$ for $15 \mathrm{~min}$ and $121^{\circ} \mathrm{C}$ for $15 \mathrm{~min}$.

\section{Preparation of seaweed extracts}

Extraction was carried out by the procedure reported by Ganesan et al. (2008) with some minor modifications. Seaweed samples (5 gm) were ground with liquid nitrogen and extracted with $50 \mathrm{~mL}$ methanol $(60 \%)$ under nitrogen atmosphere for $2 \mathrm{~h}$. The extraction was carried out at $40{ }^{\circ} \mathrm{C}$ at $100 \mathrm{rpm}$ in a shaker incubator (Innova 42; Mason Technology, Dublin, Ireland). Samples were then centrifuged at $10000 \mathrm{rpm}$ for $15 \mathrm{~min}$ (Sigma 2K15; Mason Technology) and the resulting extract (yield = $60 \mathrm{mg} \mathrm{g}^{-1}$ ) was evaporated to dryness under vacuum (Syncore Polyvap; Mason technology).

\section{Antimicrobial activity}

Microbial culture preparation

Two species of common food pathogenic and food spoilage bacteria selected for this study were Listeria monocytogenes ATCC 19115, Salmonella abony NCTC
6017, Enterococcus faecalis ATCC 7080 and Pseudomonas aeruginosa ATCC 27853, respectively (Medical Supply Company, Dublin, Ireland). All cultures were maintained at $70{ }^{\circ} \mathrm{C}$ in $20 \%$ glycerol stocks and grown in Tryptic Soy Broth (TSB) at $37^{\circ} \mathrm{C}$; apart from $P$. aeruginosa which was incubated at $30^{\circ} \mathrm{C}$ to obtain subcultures. Working cultures for each bacterium were prepared from sub-cultures and grown for $18 \mathrm{~h}$. Bacterial suspensions were then prepared in saline solution $(\mathrm{NaCl} 0.85 \%$; BioMérieux, Marcy l'Etoile France) equivalent to a McFarland standard of 0.5 , using the Densimat photometer (BioMérieux Inc.). This suspension was then diluted in TSB to obtain a working concentration of $1 \times 10^{6}$ colony forming units (CFU) $\mathrm{mL}^{-1}$.

\section{Antimicrobial activity assay}

The influence of varying concentrations of extract on inactivation efficacy against the four organisms was assessed using 96-well microtitre plates (Sarstedt Ltd, Leicester, UK). Methanolic extracts $(0.3 \mathrm{gm})$ obtained from seaweeds were dissolved in $2.5 \mathrm{~mL}$ TSB and $200 \mu \mathrm{L}$ was added to the first row of plate (concentration: $60 \mathrm{mg} \mathrm{mL}^{-1}$ ). All other wells were filled with $100 \mu \mathrm{L}$ of TSB and two fold serial dilutions were done along each column. $100 \mu \mathrm{L}$ of bacterial suspension was added to the wells. The last column was used for bacterium and media controls and sample blanks were prepared for all of the extracts. Absorbance readings were taken at 0 and $24 \mathrm{~h}$ at $600 \mathrm{~nm}$ using a microplate spectrophotometer (Powerwave; Biotek, Winooski, VT, USA) with $20 \mathrm{~s}$ agitation before each optical density (OD) measurement. Sodium benzoate and sodium nitrite were used as positive controls. Percentage inhibition was calculated according to eqn 1 :

$$
\operatorname{Inhibition}(\%)=\frac{\mathrm{O}-\mathrm{E}}{\mathrm{O}} \times 100
$$

where $\mathrm{O}$ is $(\mathrm{OD}$ of the organism at $24 \mathrm{~h}-\mathrm{OD}$ of the organism at $0 \mathrm{~h}$ ) and $\mathrm{E}$ is (OD of the organism in the presence of extract at $24 \mathrm{~h}$ - blank at $24 \mathrm{~h})-(\mathrm{OD}$ of the organism in the presence of extract at $0 \mathrm{~h}$ - blank at 0 h) (Casey et al., 2004).

\section{Microbiological analysis}

\section{Surface microflora studies}

Seaweeds were washed under running water, cut in $2 \mathrm{~cm}$ square pieces and washed again in deionised water. A $5 \mathrm{gm}$ sample of washed seaweeds was suspended in $25 \mathrm{~mL}$ of deionised water. These were autoclaved at different time and temperature combinations (section 2.2). The autoclaved flasks containing seaweeds and water were kept in a shaking incubator at $50 \mathrm{rpm}$ and $37^{\circ} \mathrm{C}$ for $48 \mathrm{~h}$. Microbiological analyses were per- 
formed at $0 \mathrm{~h}$ and after $48 \mathrm{~h}$ incubation. Serial dilutions were prepared in Maximum Recovery Diluent (MRD) and $100 \mu \mathrm{L}$ of the broth was spread on the following media: (i) Plate Count Agar (PCA; Scharlau Chemie, Barcelona, Spain), for the enumeration of total viable count; (ii) PCA $+2 \% \mathrm{NaCl}$ for enumeration of halophillic bacteria; (iii) PCA $+6 \% \mathrm{NaCl}$ for enumeration of extreme halophillic bacteria (iv) and Sabourand Dextrose agar (SDA, Scharlau Chemie), for yeast and mould. Plates were incubated at $37^{\circ} \mathrm{C}$ in case of PCA; $30{ }^{\circ} \mathrm{C}$ for PCA containing $\mathrm{NaCl}$ and $25{ }^{\circ} \mathrm{C}$ for SDA. Counting of the cultrable cells for CFU estimation was done after $24 \mathrm{~h}$ incubation for all the media except SDA for which the plates were incubated for 5 days. Results were expressed as $\mathrm{CFU} \mathrm{mL} \mathrm{m}^{-1}$.

\subsubsection{Identification of seaweeds surface microflora}

The colonies obtained on different media as outlined in the previous section were purified to determine the nucleic acid sequence using $16 \mathrm{~S}$ rRNA. A total of sixteen colonies based on the difference in colour and morphology were picked up from the plates. The isolates were sent to Geneius Lab, NewCastle, UK for $16 \mathrm{~S}$ rRNA sequencing. Primers 27f(5'-AGAGTTTGATCMTGGCTCAG-3') and 1525r (5'AAGGAGGTGWTCCARCC-3') were used for the amplification of 16S rRNA gene. The sequences were submitted to Genbank.

\section{Statistical analysis}

All the experiments were carried out in triplicate and replicated at least twice. Results are expressed as mean \pm standard deviation. All statistical analyses were carried out using STATGRAPHICS Centurion $X V$. Statistical differences between extract activities were determined using ANOVA followed by Least Significant Difference (LSD) testing. Differences were considered statistically significant when $P<0.05$.

\subsection{Nucleotide sequence accession numbers}

All sequences determined in this study are available at GenBank under the accession numbers GU071189GU071202.

\section{Results and discussion}

\section{Effect of heat on the antimicrobial properties of seaweeds}

The preliminary phytochemical analysis of the seaweeds used in the present study have been studied and reported (Cox et al., 2009). The antibacterial activity of three brown seaweeds was assessed against food pathogenic and spoilage bacteria using the microtitre plate-based dilution method (Figs 1,2, S1). The selection of the pathogenic microbes (L. monocytogenes and S. abony) was made after discussion with the Food Safety Authority of Ireland (FSAI) as these were found to be the most challenging organisms for the safety of food products in Ireland. The other two organisms ( $E$. faecalis and $P$. aeruginosa) are the most widespread food spoilage micro-organisms which are resistant to the majority of commonly used antibiotics and antimicrobial agents.

The crude extracts obtained from the raw seaweeds showed strong antimicrobial activity against all the four bacterial organisms studied (Table 1). The crude extracts of $H$. elongata were the most potent and had more than $98 \%$ inhibitory activity against $E$. faecalis, $L$. monocytogenes and $P$. aeruginosa at a concentration of $60 \mathrm{mg} \mathrm{mL}^{-1}$. In case of L. saccharina greater than $90 \%$ inhibition was seen against $L$. monocytogenes, $S$. abony and $P$. aeruginosa. For $L$. digitata, an extract concentration of $60 \mathrm{mg} \mathrm{mL}^{-1}$ could achieve $70.7-97.5 \%$ inhibition; the maximum being against $L$. monocytogenes. For antimicrobial action against $L$. monocytogenes; there was no significant difference between the $L$. digitata and $H$. elongata extracts; however the extracts (a)

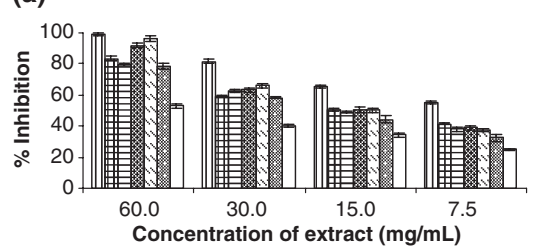

(c)

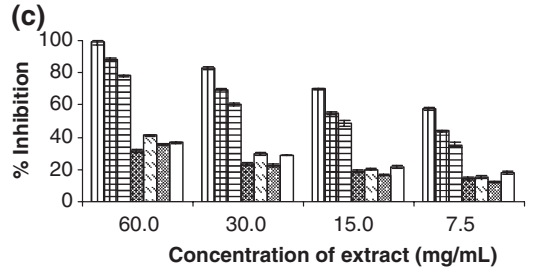

(b)

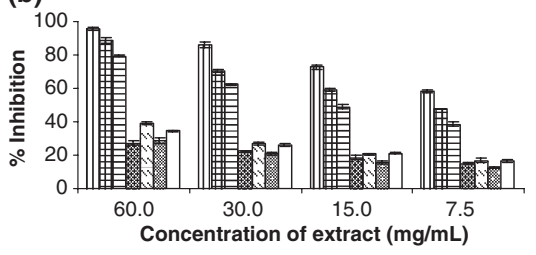

(d)

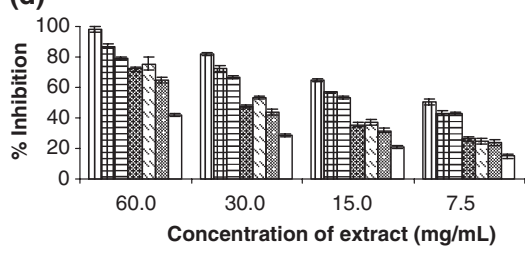

Figure 1 Antimicrobial analysis of $H$. elongata at different time/temperature combinations against food spoilage and food pathogenic bacteria. (a) Listeria; (b) Salmonella; (c) Pseudomonas; (d) Enterococcus (四: Raw; 田: $85^{\circ} \mathrm{C} / 15 \mathrm{~min}$; 目: $85^{\circ} \mathrm{C} / 30 \mathrm{~min}$; $95^{\circ} \mathrm{C} / 15 \mathrm{~min}$; 目: $100{ }^{\circ} \mathrm{C} / 15 \mathrm{~min}$; 橉: $\left.110^{\circ} \mathrm{C} / 15 \mathrm{~min} ; \square: 121^{\circ} \mathrm{C} / 15 \mathrm{~min}\right)$. 
(a)

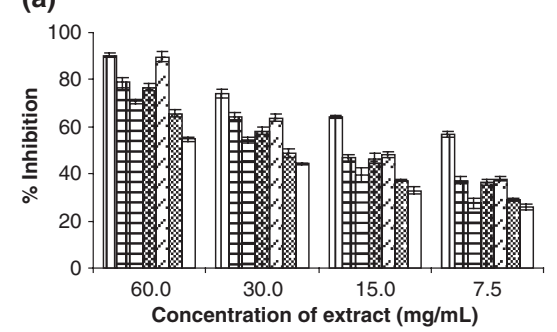

(c)

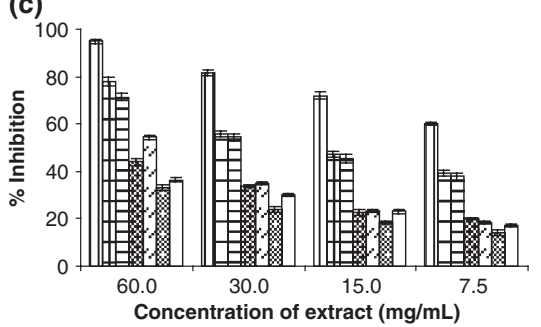

(b)

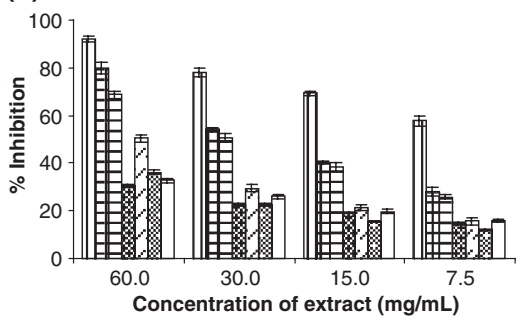

(d)

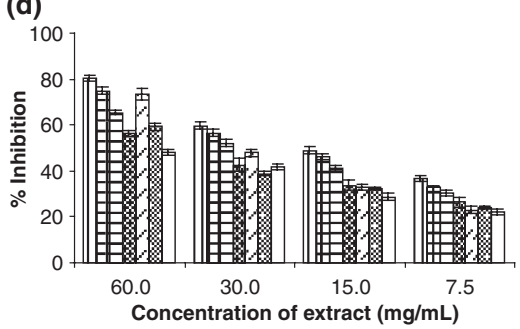

Figure 2 Antimicrobial analysis of L. saccharina at different time/temperature combinations against food spoilage and food pathogenic bacteria. (a) Listeria; (b) Salmonella; (c) Pseudomonas; (d) Enterococcus (四: Raw; 田: $85^{\circ} \mathrm{C} / 15 \mathrm{~min}$; 目: $85^{\circ} \mathrm{C} / 30 \mathrm{~min}$; 露: $95^{\circ} \mathrm{C} / 15 \mathrm{~min}$; 圀: $100^{\circ} \mathrm{C} / 15 \mathrm{~min}$; 圆: $\left.110^{\circ} \mathrm{C} / 15 \mathrm{~min} ; \square: 121{ }^{\circ} \mathrm{C} / 15 \mathrm{~min}\right)$. when used as an antimicrobial agent and levels not to exceed $0.1 \%$ maximum in food. Sodium nitrite is used preservative in meats and fish. According to the Code of Federal Regulations, Part 172 (food additives permitted for direct addition to food for human consumption) the level of sodium nitrite should not exceed 200 parts per million in the finished product. In the present study, sodium benzoate and sodium nitrite were used at a concentration $\left(60 \mathrm{mg} \mathrm{mL}^{-1}\right)$ similar to those of the extracts. $H$. elongata extracts showed significantly higher inhibition against $E$. faecalis $(98.1 \%)$ compared to Sodium benzoate $(89.4 \%)$ and Sodium nitrite $(93.7 \%)$ $(P<0.05)$. L. digitata extracts could give inhibition comparable to the positive controls only against $L$. monocytogenes (Table 1). For the other organisms, $L$. digitata extracts were not as strong as the positive controls. Both the positive controls had slightly better activity in contrast to the $L$. saccharina extracts. In general, the percentage inhibition for the positive controls were in the range of $89 \%-99 \%$ which was almost similar to the activity of the extracts in the present study. Thus, seaweed extracts (with the exception of $L$. saccharina) have a potential to replace the commonly used chemical food preservatives.

The concentration of the extract used in the present study was very high $\left(60 \mathrm{mg} \mathrm{mL}^{-1}\right)$. However, further studies will be carried out in our laboratories to purify these extracts so that a concentrated purified compound having antimicrobial activity at a much lesser concentration could be obtained and used as a nutraceutical in the food industry.

Shanmughapriya et al. (2008) reported that seaweeds species to be active against Gram negative bacteria similar to the results found in the present study. Extracts from the brown seaweed species Stoechospermum marginatum and Cladophora prolifera at a concentration of 



Figure 3 Microbiological analysis of seaweeds at different temperature/time combinations. (a) Laminaria saccharina; (b) Laminaria digitata; (c) Himanthalia elongata. 四 PCA; 刃 PCA $+2 \% \mathrm{NaCl}$; 目 $\mathrm{PCA}+6 \% \mathrm{NaCl}$.
$500 \mu \mathrm{g} \mathrm{mL}^{-1}$ were not able to inhibit most of the bacterial strains used by Ely et al. (2004). However, in comparison to the present study, $H$. elongata extracts $\left(0.7 \mathrm{mg} \mathrm{mL}^{-1}\right)$ were able to result in $45 \%$ inhibition which is almost similar to the extract concentration used by Ely et al. (2004). Most of the studies done till date use the agar disc diffusion method for describing the antimicrobial activities. This technique produces predominantly qualitative results (Casey et al., 2004) and there can be interpretational problems due to in-growth in the zone of inhibition (Piliouras et al., 2002). In comparison, microtitre plate-based assay, used in present study, is a robust and quantitative method which can reproducibly calculate the minimum inhibitory concentration of the bioactive compounds present.

Heat applications at $100^{\circ} \mathrm{C}$ (boiling) and $121{ }^{\circ} \mathrm{C}$ (autoclaving) are common practices in the processing of food products in order to render them palatable and microbiologically safe. Since seaweed would need to undergo some heat treatment prior to usage, it was relevant to assess the effects of heat treatment on the stability of seaweed antimicrobial properties. In comparison to the antimicrobial activity of raw seaweeds, heat treated seaweeds showed fluctuations in their antimicrobial content (activity of the extract) over the range of temperatures investigated. In general, there was a decreasing trend in the bactericidal activity; at higher heating temperatures, the inhibition was weaker. There was no significant difference in the inhibition obtained by heating at $85{ }^{\circ} \mathrm{C}$ for 15 and $30 \mathrm{~min}(P<0.05)$. Nonetheless, after $30 \mathrm{~min}$ of heating, the antimicrobial effect of seaweeds was lower than that of seaweeds heated for $15 \mathrm{~min}$ against all the organisms. Thus, for further experimentation heat treatments for $30 \mathrm{~min}$ was not used. For all the seaweeds species studied, heating at $85^{\circ} \mathrm{C}$ for $15 \mathrm{~min}$ or $30 \mathrm{~min}$ showed different antimicrobial effects to those heated at $95{ }^{\circ} \mathrm{C}$ for $15 \mathrm{~min}$. This effect was more pronounced against Gram negative bacteria wherein two different temperature groups (Figs 1-3) could be clearly seen; those having inhibition in the range of less than $40 \%\left(95-121{ }^{\circ} \mathrm{C}\right.$ for $\left.15 \mathrm{~min}\right)$ and those having inhibition values close to the raw seaweeds $\left(85^{\circ} \mathrm{C}\right.$ for 15 and $\left.30 \mathrm{~min}\right)$. In all the cases, the antimicrobial content decreased upon heating at $95^{\circ} \mathrm{C}$

Table 1 Percentage inhibition of most effective concentrations $\left(60 \mathrm{mg} \mathrm{mL}^{-1}\right)$ of methanolic extracts of three seaweed species and the positive controls against food pathogenic ${ }^{\mathrm{a}}$ and food spoilage ${ }^{\mathrm{b}}$ bacteria

\begin{tabular}{llllll}
\hline & H. elongata & L. digitata & L. saccharina & Sodium benzoate & Sodium nitrite \\
\hline${\text {. } \text { monocytogenes }^{\mathrm{a}}}$ & $98.7 \pm 0.8^{\mathrm{p}}$ & $97.5 \pm 2.6^{\mathrm{p}}$ & $90.4 \pm 1.1^{\mathrm{q}}$ & $96.5 \pm 4.1^{\mathrm{p}}$ & $96.2 \pm 2.9^{\mathrm{p}}$ \\
S. abony $^{\mathrm{a}}$ & $95.6 \pm 0.8^{\mathrm{p}}$ & $87.5 \pm 1.3^{\mathrm{q}}$ & $92.3 \pm 1.3^{\mathrm{r}}$ & $97.3 \pm 3.1^{\mathrm{p}}$ & $98.4 \pm 2.2^{\mathrm{p}}$ \\
E. faecalis $^{\mathrm{b}}$ & $98.1 \pm 1.7^{\mathrm{p}}$ & $77 \pm 2.3^{\mathrm{q}}$ & $80.5 \pm 1.4^{\mathrm{r}}$ & $89.4 \pm 3.7^{\mathrm{s}}$ & $93.7 \pm 2.2^{\mathrm{s}}$ \\
${\text { P. } \text { aeruginosa }^{\mathrm{b}}}^{98.7 \pm 1.2^{\mathrm{p}}}$ & $70.7 \pm 1.1^{\mathrm{q}}$ & $94.8 \pm 1.1^{\mathrm{r}}$ & $99.1 \pm 0.6^{\mathrm{p}}$ & $97.3 \pm 2.7^{\mathrm{pr}}$ \\
\hline
\end{tabular}

Each value is presented as mean $\pm \mathrm{SD}(n=6)$. Means within each row with different letters $(p-s)$ differ significantly $(P<0.05)$. Statistical comparison is between the three seaweed species and the positive controls against each organism. 
for $15 \mathrm{~min}$ and then increased when the seaweeds were heated at $100{ }^{\circ} \mathrm{C}$ for $15 \mathrm{~min}$. The result of this effect was best seen in case of $H$. elongata and $L$. saccharina (heat treated at $100{ }^{\circ} \mathrm{C}$ for $15 \mathrm{~min}$ ) extracts against $L$. monocytogenes. The heat treated extracts from these species $\left(60 \mathrm{mg} \mathrm{mL}^{-1}\right)$ had almost similar inhibition activity as compared to the raw seaweeds. Hsieh (2000) indicated that cinnamon extract was stable after heat treatments up to $100{ }^{\circ} \mathrm{C}$ for $20 \mathrm{~min}$ and its antimicrobial effect was also enhanced.

In case of $H$. elongata, increasing the temperature severely reduced the antimicrobial efficacy of the extracts against Gram negative organisms (Fig. 1). Seaweeds heat treated at $95{ }^{\circ} \mathrm{C}$ for $15 \mathrm{~min}$ and above were found to be significantly different from the raw seaweeds $(P<0.05)$. For the Gram positive bacteria the activity reduced gradually and became less than $40 \%$ (for the most concentrated extract) only when the seaweed was heated at $121{ }^{\circ} \mathrm{C}$ for $15 \mathrm{~min}$. In case of L. saccharina (Fig. 2) and L. digitata (Fig. S1) Gram negative bacteria were less prone to heat treated extracts. As the temperature was increased from $85{ }^{\circ} \mathrm{C}$ for $30 \mathrm{~min}$ to $95{ }^{\circ} \mathrm{C}$ for $15 \mathrm{~min}$, the inhibition reduced to less than $40 \%$. The extracts from $L$. digitata, showed a different trend as compared to the other two species whereby the antimicrobial activity decreased gradually when heated at $85{ }^{\circ} \mathrm{C}$ for $15 \mathrm{~min}$ and then a very large decrease was observed at $95{ }^{\circ} \mathrm{C}$ for $15 \mathrm{~min}$. This effect was seen for all the four bacterial organisms studied. For the other two seaweed species, the sudden fall in activity at $95{ }^{\circ} \mathrm{C}$ was seen only for Gram negative bacteria. In general, antimicrobial content has been reported to reduce as heating temperature in increased in case of herbs and spices like garlic (Kim et al., 2002).

Since the desire for the natural foods by consumers is increasing, the development of food products containing seaweeds would provide the consumers with not only dietary fibre but also other bioactive components. The challenge is to purify and incorporate these natural antimicrobials in foods without affecting the sensory and nutritional properties of foods. The present study tried to achieve some of this by reporting the antimicrobial activity of the extract and monitoring the changes in the activity during heat processing with the help of a number of food spoilage and pathogenic micro-organisms.

\section{Microbiological analysis}

Surface microflora studies

It is important to examine the microbiological aspects relating to seaweeds as they could be consumed raw and may originate from an environment which may contain faecal and other human clinical pathogens. Results from the microbiological analysis are presented in Fig. 3. The initial quality of raw seaweeds was good, as indicated by a complete absence of growth at $0 \mathrm{~h}$ in the raw seaweeds. Since $37^{\circ} \mathrm{C}$ is the favourable temperature for bacterial growth, the flasks containing seaweeds and water were incubated at $37^{\circ} \mathrm{C}$ for $48 \mathrm{~h}$ to allow the growth of bacteria or spores that might be present. After $48 \mathrm{~h}$, the broth from the incubated flasks was plated on the different media plates. No growth was obtained on any of the different media plates showing complete absence of any live microbial cultures in raw seaweeds. This observation was in line with the fact that seaweeds are eaten raw in many countries and there were no reports of any food safety issues related to their raw consumption. However, it was also important to see the microbial load at the temperatures generally used for processing $\left(85-100{ }^{\circ} \mathrm{C}\right)$ in food industries. For the initial trials, the seaweed species were also heated at $85^{\circ} \mathrm{C}$ for $30 \mathrm{~min}$ to allow investigating the effect of longer heating time on the microbiological status of seaweeds. No growth of bacteria or fungal cultures on any kind of media was found when plating was done immediately after autoclaving $(0 \mathrm{~h})$ at $85{ }^{\circ} \mathrm{C}$ for $15 \mathrm{~min}$. After $48 \mathrm{~h}$ of incubation, when the broth from heat treated $L$. saccharina and $L$. digitata flasks was plated, total aerobic bacterial counts obtained were as high as $2 \times 10^{8}-3.8 \times 10^{8} \quad\left(8.4 \pm 0.13 \log \mathrm{cfu} \mathrm{mL} \mathrm{m}^{-1}\right)$ and $2.7 \times 10^{8}-3.1 \times 10^{8}\left(8.4 \pm 0.04 \log \mathrm{cfu} \mathrm{m} \mathrm{m}^{-1}\right)$, respectively. Among all the three species, $H$. elongata treated at $85{ }^{\circ} \mathrm{C}$ for $15 \mathrm{~min}$ was found to contain the minimal aerobic bacterial load $\left(1.7 \times 10^{4}-3 \times 10^{4} ; 4.4 \pm 0.14\right.$ $\log \mathrm{cfu} \mathrm{mL}^{-1}$ ) as compared to the other two seaweed species. Similar results were obtained for plates containing PCA and different concentrations of $\mathrm{NaCl}$. It is probable that heating at $85^{\circ} \mathrm{C}$ resulted in germination of spores or dormant cells. The Laminaria species are a rich source of carbohydrate storage compounds like mannitol or laminaran (MacArtain et al., 2007). It is likely that heating resulted in starch hydrolysis and made the sugars readily available for the spores to grow and leading to the observed high microbial numbers.

In case of $L$. digitata and $H$. elongata, heating at $85{ }^{\circ} \mathrm{C}$ for 30 min resulted in reduction in the total number of microbial cells observed whereas for $L$. saccharina, heating for a longer time did not seem to have much effect on microbial destruction and it even increased the growth on media containing PCA and $6 \% \mathrm{NaCl}$. It is worth noting that there was not much difference between the antimicrobial content among the seaweeds heated at $85{ }^{\circ} \mathrm{C}$ for 15 and $30 \mathrm{~min}$. Thus, further experiments were carried out at different temperatures keeping the time constant at $15 \mathrm{~min}$. In the next set of experiments, seaweeds were heated at $95{ }^{\circ} \mathrm{C}$ for $15 \mathrm{~min}$ and $100{ }^{\circ} \mathrm{C}$ for $15 \mathrm{~min}$. Plating was done at $0 \mathrm{~h}$ and after $48 \mathrm{~h}$ of incubation. No bacterial or fungal growth was observed on any of the plates. It was assumed that heating at such high temperatures could have been detrimental for the bacterial species and resulted in 
complete destruction. The maximum microbial load allowed on pre-cut fruits and vegetables (ready to eat) according to FSAI guidelines (Commission Regulation (EC) No 2073/2005) is only $1000 \mathrm{cfu} \mathrm{g}^{-1}$. Although the raw seaweeds were of initial good quality; heating at $85{ }^{\circ} \mathrm{C}$ resulted in the germination of surface spores. Thus, the seaweeds would need to be processed at temperatures above $95{ }^{\circ} \mathrm{C}$ in order to ensure complete inactivation of all bacteria.

Yeasts and moulds were not detected on the seaweed species studied. The same has been reported earlier for the microbiological studies carried out with red alga, Palmaria palmata (Moore et al., 2002). Microbes are very readily present in the seawater than that in air. Marine plants and animals are continually exposed to high concentrations of potentially harmful microbes. Still, the raw seaweeds which lack cell-based inducible immune responses were free from any contaminating organisms which could be attributed to their antimicrobial defence systems such that the colonisation of the bacterial species on the surface of the seaweeds could not take place. Vairappan et al. (2001) reported on the antibacterial potential of halogenated compounds isolated from the Malaysian Laurencia against marine bacteria from the algal habitat suggesting the possible role played by these halogenated compounds as the seaweed's chemical defence substances. In the present study also crude extracts obtained upon extraction with methanol had the ability to kill most of the Gram positive and Gram negative bacteria. These antimicrobials which are mostly secondary metabolites in nature might be serving as feeding deterrents against marine herbivores.

\section{Identification of seaweed microbiota}

Marine surface communities generally form as a result of the constant mixing and entrapments of the millions of microbial cells typically found in seawater. Hence, a better understanding of the diversity of microbial communities on marine living surfaces may provide opportunities to access members of the poorly understood communities in seawater. In order to determine the nature of bacterial species obtained upon heating at $85^{\circ} \mathrm{C}$, the isolates were identified by automated sequencing of the hyper variable region of $16 \mathrm{~S}$ rRNA gene using $27 \mathrm{f}$ and $1525 \mathrm{r}$ primers (Lane, 1991). Analysis of the 16S rRNA gene sequences revealed that members belonging to Bacillus dominated the culture collection. The genus Bacillus is widely distributed across many terrestrial and aquatic habitats including marine sediments (Mirinda et al., 2008). Among the numerous Bacillus species, generally species of $B$. subtilis, B. cereus and B. lichenifirmis, have been detected from marine environments including seawater (Ivanova et al., 1999). In the present study, H. elongata did not have any diversity in the type of species present on it. The organism isolated was found to be similar to
Bacillus subtilis subtilis ATCC 6051 with a percentage match of more than $99 \%$. B. subtilis spores can survive the extreme heating that is often used to process food. This might be the reason that their presence was seen once the seaweeds were heated. L. digitata was rich in bacteria belonging to Enterobacteriaceae (Enterobacter asburiae and Enterobacter hormaechei) and Bacillaceae (Bacillus subtilis subtilis ATCC 6051) family. The species found on $L$. saccharina were more diverse including Bacillus subtilis subtilis ATCC 6051, Acinetobacter genomospecies 9, Bacillus subtilis spizizenii, Paenibacillus ehimensis and Bacillus licheniformis. Since Gram negative bacteria are non spore formers it might be possible that the species belonging to Enterobacteriaceae became dormant under stressful conditions (Sachidanandham \& Gin, 2009). When heat was applied, it might have resulted in the hydrolysis of sugars and other nutrients present in seaweeds, required for their growth. Staufenberger et al. (2008) carried out the phylogenetic analysis of bacteria associated with L. saccharina and reported the presence of Alphaproteobacteria, Gammaproteobacteria and Bacteroidetes group; similar to those found in the present study. Several Bacillus, Halomonas, Paenebacillus and Clostridium spp., are well known for their broad salt tolerance, being able to tolerate salinities of $10 \% \mathrm{NaCl}$ or even greater. A number of bacteria such as Bacillus and Paenebacillus isolated in present study have been also reported from other seaweeds (Lee \& Kim, 2007; Tiquia et al., 2007).

To date, there have been few reports in the literature regarding the safety of edible seaweeds. Studies on the safety of edible seaweeds in the St Lawrence River, Canada described heavy metal contamination; however their microbiological status was not investigated (Phaneuf et al., 1999). Some studies on corals suggest that marine living surfaces have host-specific and generally stable communities that are distinct from the surrounding planktonic microorganisms (Perez-Matos et al., 2007). However, in the present study most of the organisms found by the $16 \mathrm{~S}$ rRNA sequencing were similar to those found on land. It is possible as brown seaweeds are rich sources of antimicrobials they do not allow indigenous microflora present in sea to grow and survive on them. This was proved by the complete absence of any microflora on raw seaweeds. However, the microflora found after the heat treatment could be a result of the spore germination or revitalising of dormant cells.

\section{Conclusion}

The present study reports on the antimicrobial content of brown Irish edible seaweeds. $H$. elongata was the best species in terms of inhibition against all the different microbial organisms tested in this study. Methanolic extracts of the seaweed species studied showed maximum inhibition against $L$. monocytogenes. This study suggests 
the possibility of using seaweeds extracts as natural antimicrobials in the food industry. The tested extracts were almost equally active in comparison to the synthetic preservatives like sodium benzoate and sodium nitrite. The microbial diversity of the seaweeds demonstrated that raw seaweeds are of good microbiological status. However, the presence of several halophilic genera and spore forming species was seen upon heating. These were successfully inactivated at temperatures above $95^{\circ} \mathrm{C}$.

\section{Acknowledgments}

The authors would like to acknowledge funding from the Irish government under the Technological Sector Research Scheme (Strand III) of the National Development Plan.

\section{References}

Breena, W.M. (1994). Healthfulness and nutritional quality of fresh versus processed fruits and vegetables: a review. Journal of Food Service Systems, 8, 1-45.

Casey, J.T., O'Cleirigh, C., Walsh, P.K. \& O'Shea, D.G. (2004). Development of a robust mocrotiter plate-based assay method for assessment of bioactivity. Journal of Microbiological Methods, 58, $327-334$.

Cox, S., Abu-Ghannam, N. \& Gupta, S. (2009). An assessment of the antioxidant and antimicrobial activity of six species of edible Irish Seaweeds. International Food Research Journal, 17, 205-220.

Dowling, P.M. (2004). Antimicrobial therapy. In: Equine Clinical Pharmacology (edited by J.J. Bertone \& L.J.I. Horspool). Pp. 13-48. London: Saunders, Elsevier Ltd.

Dubber, D. \& Harder, T. (2008). Extracts of Ceramium rubrum, Mastocarpus stellatus and Laminaria digitata inhibit growth of marine and fish pathogenic bacteria at ecologically realistic concentrations. Aquaculture, 274, 196-200.

Ely, R., Supriya, T. \& Naik, C.G. (2004). Antimicrobial activity of marine organisms collected off the coast of South East India. Journal of Experimental Marine Biology and Ecology, 309, 121-127.

Febles, C.I., Arias, A., Hardisson, A., Ldpez, A.S. \& Gil-Rodriguez, M.C. (1995). Antimicrobial activity of extracts from some Canary Species of Phaeophyta and Chlorophyta. Phytotherapy Research, 9, 385-387.

Ganesan, P., Chandini, S.K. \& Bhaskar, N. (2008). Antioxidant properties of methanol extract and its solvent fractions obtained from selected Indian red seaweeds. Bioresource Technology, 99, 2717-2723.

Hsieh, P.C. (2000). Antimicrobial effect of cinnamon extract. Taiwanese Journal of Agricultural Chemistry and Food Science, 38, 184-193.

Ivanova, E.P., Vysotskii, M.V. \& Svetashev, etal. (1999). Characterisation of Bacillus strains of marine origin. International microbiology, 2, 267-271.

Kim, J.Y., Lee, Y.C. \& Kim, K.S. (2002). Effect of heat treatments on the antimicrobial activities of Garlic (Allium sativum). Journal of Microbiology and Biotechnology, 12, 331-335.

Lane, D.J. (1991). S/23S rRNA sequencing. In: Nucleic Acid Techniques in Bacterial Systematics (edited by E. Stackebrandt \& M. Goodfellow). Pp. 115-175. New York, NY: John Wiley \& Sons.

Lee, S.D. \& Kim, S.J. (2007). Aeromicrobium tamlense sp. nov., isolated from dried seaweed. International Journal of Systematic and Evolutionary Microbiology, 57, 337-341.

MacArtain, P., Gill, C.I.R., Brooks, M., Campbell, R. \& Rowland, I.R. (2007). Nutritional value of edible seaweeds. Nutrition Reviews, 65, 535-43.
McHugh, D.J. (2003). A Guide to the Seaweed Industry. FAO Fisheries Technical Paper 441. Rome: Food and Agricultural Organisation of the United Nations.

Mirinda, C.A., Martins, O.B. \& Clementino, M.M. (2008). Specieslevel identification of Bacillus strains isolates from marine sediments by conventional biochemical, 16S rRNA gene sequencing and intertRNA gene sequence length analysis. Antonie van Leeuwenhoek, 93, 297-304.

Moore, J.E., Xu, J. \& Millar, B.C. (2002). Diversity of the microflora of edible macroalga (Palmaria palmata). Food Microbiology, 19, 249-257.

Nagayama, K., Iwamura, Y., Shibata, Y., Hirayama, I. \& Nakamura, T. (2002). Bactericidal activity of phlorotannins from the brown alga Ecklonia kurome. Journal of Antimicrobial Chemotherapy, 50, 889893.

Perez-Matos, A., Rosado, W. \& Govind, N. (2007). Bacterial diversity associated with the Caribbean tunicate Ecteinascidia turbinata. Antonie van Leeuwenhoek, 92, 155-164.

Phaneuf, D., Cote, I., Dumas, P., Ferron, L.A. \& LeBlanc, A. (1999). Evaluation of the contamination of marine algae (seaweed) from the St. Lawrence River and likely to be consumed by humans. Environmental Research, 80, S175-S182.

Piliouras, P., Ulett, G.C., Ashhusrt-Smith, C., Hirst, R.G. \& Norton, R.E. (2002). A comparison of antibiotic susceptibility testing methods for cotrimoxazole with Bukholderia pseudomallei. International Journal of Antimicrobial Agents, 19, 427-429.

Sachidanandham, R. \& Gin, Y.H. (2009). A dormancy state in nonspore-forming bacteria. Applied Microbiology and Biotechnology, 81, 927-941.

Seafoodplus, 2008. http://www.seafoodplus.org/fileadmin/files/news/ 2004-01-22SFRTD1launchBrussels.pdf (Accessed on March 25, 2009).

Shanmughapriya, S., Manilal, A., Sujith, S., Selvin, J., Kiran, G.S. \& Natarajaseenivasan, K. (2008). Antimicrobial activity of seaweeds extracts against multiresistant pathogens. Annals of Microbiology, 58, 535-541.

Smit, A.J. (2004). Medicinal and pharmaceutical uses of seaweed natural products: a review. Journal Applied Phycology, 16, 245262.

Staufenberger, T., Theil, V., Wises, J. \& Imhoff, J.F. (2008). Phylogenetic analysis of bacteria associated with Laminaria saccharina. FEMS Microbiology Ecology, 64, 65-77.

Tiquia, S.M., Davis, D., Hadid, H. et al. (2007). Halophilic and halotolerant bacteria from river waters and shallow groundwater along the rouge river of southeastern Michigan. Environmental Technology, 28, 297-307.

Vairappan, C.S., Daitoh, M., Suzuki, M., Abe, T. \& Masuda, M. (2001). Antibacterial halogenated metabolites from the Malaysian Laurencia species. Phytochemistry, 58, 291-297.

\section{Supporting information}

Additional Supporting Information may be found in the online version of this article:

Figure S1. Antimicrobial analysis of $L$. digitata at different time/temperature combinations against food spoilage and food pathogenic bacteria. (a) Listeria; (b) Salmonella; (c) Pseudomonas; (d) Enterococcus.

Please note: Wiley-Blackwell are not responsible for the content or functionality of any supporting materials supplied by the authors. Any queries (other than missing material) should be directed to the corresponding author for the article. 